\title{
Van bloedzuiger naar stamceltransplantatie; ... en terug??
}

Citation for published version (APA):

Schouten, H. C. (2004). Van bloedzuiger naar stamceltransplantatie; ... en terug?? Maastricht University. https://doi.org/10.26481/spe.20040528hs

Document status and date:

Published: 28/05/2004

DOI:

10.26481/spe.20040528hs

Document Version:

Publisher's PDF, also known as Version of record

\section{Please check the document version of this publication:}

- A submitted manuscript is the version of the article upon submission and before peer-review. There can be important differences between the submitted version and the official published version of record.

People interested in the research are advised to contact the author for the final version of the publication, or visit the DOI to the publisher's website.

- The final author version and the galley proof are versions of the publication after peer review.

- The final published version features the final layout of the paper including the volume, issue and page numbers.

Link to publication

\footnotetext{
General rights rights.

- You may freely distribute the URL identifying the publication in the public portal. please follow below link for the End User Agreement:

www.umlib.nl/taverne-license

Take down policy

If you believe that this document breaches copyright please contact us at:

repository@maastrichtuniversity.nl

providing details and we will investigate your claim.
}

Copyright and moral rights for the publications made accessible in the public portal are retained by the authors and/or other copyright owners and it is a condition of accessing publications that users recognise and abide by the legal requirements associated with these

- Users may download and print one copy of any publication from the public portal for the purpose of private study or research.

- You may not further distribute the material or use it for any profit-making activity or commercial gain

If the publication is distributed under the terms of Article $25 \mathrm{fa}$ of the Dutch Copyright Act, indicated by the "Taverne" license above, 
863 


\section{Van bloedzuiger naar}

stamceltransplantatie;

... en terug?? 


\section{Colofon}

Basisontwerp en realisatie: Unigraphic, Universiteit Moastricht.

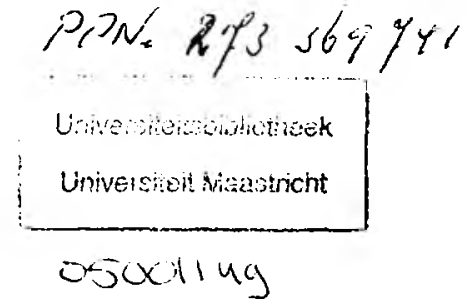

ISBN 90-5681-201-7

NUR 878

Alle rechten voorbehouden. Niets uit deze uitgave mag worden verveelvoudigd, opgeslagen in een geautomatiseerd gegevensbestand of openbaar gemaakt, zonder voorafgaande schriftelijke toestemming van de auteur of uitgever. 


$$
\begin{aligned}
& m G \\
& V A C \\
& 57^{2}
\end{aligned}
$$

\section{Van bloedzuiger naar stamceltransplantatie; ... en terug??}

Rede

uitgesproken bij de aanvaarding van het ambt van bijzonder hoogleraar interne Geneeskunde in het bijzonder de intensieve haematologische zorg en stamceltransplantatie aan de Universiteit Maastricht

Op vrijdag 28 mei 2004

Door

Dr. Harry C. Schouten 
Van bloedzuiger naar stamceltransplantatie; ... en terug?? 


\section{Van bloedzuiger naar stamceltransplantatie; ... en terug??}

Mijnheer de pro-rector, geachte aanwezigen,

Als we in van Dale's woordenboek der Nederlandse taal het woord "bloed" opzoeken, vinden we meer dan een pagina met gerelateerde woorden. Ik geef direct toe dat dit woordenboek niet op A4 maar op A5 formaat verschijnt waardoor de pagina's iets sneller gevuld zijn, maar toch betekent het dat bloed blijkbaar belangrijk is. Het kruipt zelfs waar het niet gaan kan... Zelfs met een minimale kennis van het menselijk lichaam zijn we ons allen bewust van bloed. Met bloedend hart, bloedrood, bloedmooi, etc. zijn allemaal uitdrukkingen die min of meer dagelijks worden gebruikt. Het feit dat wij hier vanmiddag met z'n allen bij elkaar zijn, geeft weer dat het bloed stroomt en ons allen in staat stelt te komen, te luisteren of eventueel te slapen. Dat u hier bent heeft ook te maken met het feit dat het blijkbaar niet altijd goed gaat met ons bloed, dat er ziektes bestaan waarbij het bloed betrokken is. Ook betekent dit misschien dat $u$ geïnteresseerd bent geraakt door de titel van deze voordracht. Bloedziektes werden in het verleden behandeld met bloedzuigers of aderlatingen en nu worden zelfs stamceltransplantaties toegepast. En ook betekent dit dat de Universiteit Maastricht het blijkbaar nodig heeft gevonden zich op dit belangrijke gebied te profileren en mij de kans biedt deze openbare les te geven over mijn vakgebied: de interne geneeskunde, in het bijzonder de haematologische intensieve zorg en stamceltransplantaties. Een hele mond vol over een belangrijk onderwerp. Hoe belangrijk bloed ook is, het aantal patiënten met bloedziektes, waarbij ik bedoel ziektes die te doen hebben met cellen die gevormd worden door het bloedvormende apparaat, het beenmerg, en daarna circuleren door het gehele lichaam is relatief beperkt. Ongeveer $7 \%$ van alle kwaadaardige ziektes in Europa betreft een aandoening van het haematologisch apparaat. Het komt wat vaker voor bij mannen dan bij vrouwen.

In 1995 was het zo dat ongeveer $3 \%$ van de mannen en $2,5 \%$ van de vrouwen gedurende hun leven een kwaadaardige haematologische ziekte ontwikkelt. In $60 \%$ van deze gevallen zijn deze patiënten ouder dan 60 jaar. Zo ziet de gemiddelde huisarts één keer per 2 jaar een nieuwe patiënt met een haematologische aandoening, variërend van één 


\begin{tabular}{|l|l|l|l|}
\hline Aantal nieuwe patiënten & Huisarts & Internist & radiotherapeut \\
\hline Ziekte van Hodgkin & 1 per 17 jaar & 3 per jaar & 2 per jaar \\
\hline NHL & 1 per 3 jaar & 14 per jaar & 10 per jaar \\
\hline M Myeloom & 1 per 10 jaar & 5 per jaar & 4 per jaar \\
\hline Acute lymfatische leukemie & 1per 80 jaar & 2 per 3 jaar & \\
\hline Acute myeloïde leukemie & 1 per 15 jaar & 3 per jaar & \\
\hline $\begin{array}{l}\text { Chronische lymfatische } \\
\text { leukemie }\end{array}$ & 1 per 18 jaar & 3 per jaar & \\
\hline $\begin{array}{l}\text { Chronische myeloïde } \\
\text { leukemie }\end{array}$ & 1per 40 jaar & 1-2 per jaar & \\
\hline
\end{tabular}

Bron: Integraal Kankercentrum Zuid

keer per 3 jaar een patiënt met een non-Hodgkin lymfoom tot één keer per 80 jaar een patiënt met een acute lymfatische leukemie (1).

\section{Haematopoiese (bloedaanmaak)}

Dagelijks worden er in het lichaam bloedcellen geproduceerd. Het betreft per dag ongeveer 240 miljard rode bloedcellen ( 170 miljoen per seconde) en 2 tot 20 miljard witte bloedcellen. Gigantische aantallen. Het gebeurt niet zomaar. Dit betekent dat deze cellen een belangrijke functie hebben anders zou het lichaam hier niet zo veel energie in stoppen.

Bloedcellen die geproduceerd worden hebben belangrijke functies:

- Zuurstoftransport

- Bloedstelping

- Bevorderen weerstand van het lichaam tegen interne en externe bedreigingen.

Om goed te kunnen begrijpen wat er gebeurt bij de haematologische intensieve zorg (een belangrijk deel van mijn leeropdracht) wil ik u graag even meenemen naar de ontwikkeling van het beenmerg, van de onrijpe beenmergcel naar de rijpe functionele cellen die in ons bloed stromen en die ons lichaam blijkbaar zo hard nodig heeft.

in ons beenmerg hebben wij onrijpe stamcellen die zich via allerlei tussenstappen ontwikkelen tot rijpe functionele bloedcellen. Deze stamcellen zijn uitermate zeldzaam; ongeveer een op de 10.000 tot 100.000 cellen in het beenmerg is een stamcel die zich kan ontwikkelen 


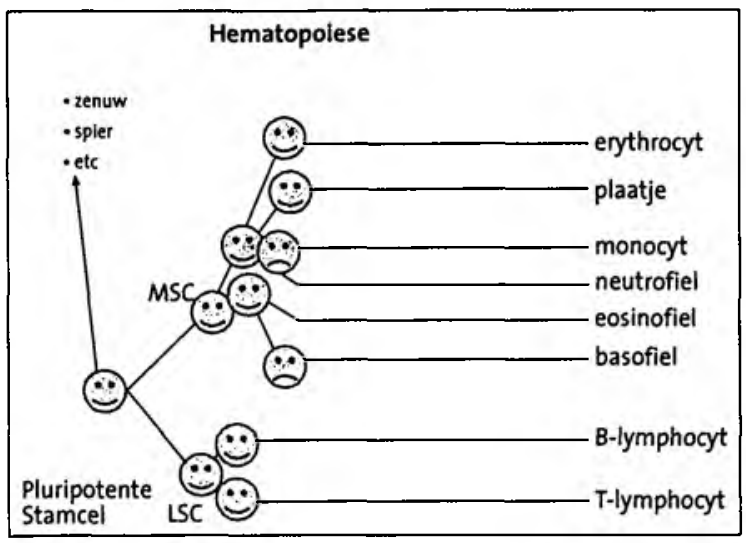

tot rode cellen, witte cellen of bloedplaatjes. Omdat deze stamicel zich nog tot zoveel andere cellen kan ontwikkelen, wordt deze cel vaak de pluripotente stamcel genoemd. Deze ontwikkeling van onrijpe naar rijpe cellen vindt plaats onder allerlei hormonale invloeden.

Allereerst bekijken we de ontwikkeling van de pluripotente stamcel tot een myeloïde stamcel. $\mathrm{Na}$ een delingsproces ontwikkelt een van de nakomelingen zich tot de myeloide stamcel en de andere cel blijft de kenmerken houden van een pluripotente stamcel zodat dit compartiment intact blijft. Dit alles is natuurlijk om te voorkomen dat er anders uitputting zou plaats vinden en er geen bloed meer gevormd kan worden. Deze myelö̈de stamcel ontwikkelt zich afhankelijk van de behoefte in het lichaam en gestuurd door allerlei groeifactoren via diverse tussenstappen tot bloedplaatjes (de trombocyten), tot erythrocyten (de rode bloedcellen) en diverse soorten granulocyten.

- Trombocyten zijn van belang voor de bloedstelping.

- De erythrocyten zijn van belang voor het zuurstoftransport.

- De granulocyten zijn van belang voor het bestrijden van allerlei infecties, vooral bacteriële infecties.

Ook kan de pluripotente stamcel zich ontwikkelen tot een lymfatische stamcel. Deze lymfatische stamcel kan zich, ook weer gestuurd door de behoefte en onder de invloed van allerlei groeifactoren, ontwikkelen tot rijpe B-lymfocyten en plasmacellen (die afweereiwitten produceren) maar ook tot rijpe T-lymfocyten en Natural Killer cellen. De B-lymfocyten en de T-lymfocyten zijn niet alleen van belang voor onze afweer tegen virussen maar ook voor de bescherming tegen andere infecties. Lymfatische cellen spelen een heel belangrijke rol in de cellulaire afweer, 
de afweer met behulp van cellen. Het betreft hier cellen die in staat zijn om te reageren op externe indringers. Op basis daarvan ontstaat niet alleen een memory cel, een geheugencel, maar ook een effectorcel die de indringer opruimt.

In grote lijnen komt het erop neer dat de onrijpe cellen in het beenmergcompartiment zitten. Ze zijn van belang zijn voor de toename van cellen, de proliferatie, en uiteindelijk de differentiatie (uitrijping) waarbij de uitgerijpte cellen hun functie krijgen en deze functie daar uitoefenen waar ze het meest nodig zijn en via het circulerende bloed ter plaatse komen.

\section{Haematologische maligniteiten en hun behandeling}

Dit zeer ingewikkelde en, gezien de grote aantallen cellen die dagelijks geproduceerd worden, zeer actieve systeem is natuurlijk ook vatbaar voor allerlei verstoringen. Deze verstoringen kunnen zich op diverse manieren uiten. Het kan hier afwijkingen betreffen zoals tekorten van bepaalde cellen, een teveel ervan, of cellen met een gestoorde of afwijkende functie. Waar we vandaag met name over praten zijn de kwaadaardige ontwikkelingen van het beenmerg. Deze kunnen zich alle uiten met een tekort, een teveel of een afwijkende functie. Indien in het on rijpe compartiment een probleem ontstaat waarbij proliferatie op de voorgrond staat, ontstaat een ziektebeeld dat zich uit als een acute leukemie. Treden deze problemen op in de myeloïde hoek noemen we het een acute myeloïde leukemie. Treden deze problemen op in de lymfatische hoek dan praten we over een acute lymfatische leukemie. Als de ziekte zich meer manifesteert als een opeenstapeling van rijpe bloedcellen b.v. te veel rijpe lymfocyten, dan noemen we dit een chronische lymfatische leukemie. Krijgen we te veel plasmacellen dan noemen we het de ziekte van Kahler ofwel het multipel myeloom, krijgen we te veel erythrocyten dan praten we over polycythaemia vera, bij trombocyten over een essentiële trombocytose en als we te veel granulocyten hebben dan praten we over het ziektebeeld bekend als een chronische myeloïde leukemie. Men kan dit min of meer vergelijken met een kraan en een wastafel: indien de kraan te hard staat kan de wasbak overstromen. Hierbij staat dan met name de celaanmaak (proliferatie) op de voorgrond en praten we dus over een acute leukemie. Indien de afvoer verstopt is, hetgeen een uiting is van een geremde natuurlijke celdood (apoptose), praten we over ziektebeelden zoals de chronische leukemieën.

In de dagelijkse praktijk blijkt het iets ingewikkelder te zijn en is er 
vaak een probleem van én gestoorde proliferatie én gestoorde apoptose in wisselende verhoudingen. En de kraan én de afvoer.

Uitgebreide bestudering van deze ziektebeelden heeft ertoe geleid dat we een goed inzicht hebben gekregen in de hele haematopoiese (bloedaanmaak). Ook het in kweek brengen in het laboratorium van allerlei beenmergcellen in de aanwezigheid of afwezigheid van diverse groeifactoren heeft ons een uitgebreider inzicht gegeven in de groei en ontwikkeling van bloed en beenmerg. Op basis van dit concept hebben we ontdekt dat er een populatie cellen in het beenmerg aanwezig is die je kunt overplanten naar andere proefdieren, maar ook naar andere mensen. Deze cellen zijn dan in staat om nieuw beenmerg en nieuw bloed te vormen. Dit blijken dezelfde pluripotente stamcellen te zijn, die ik $u$ al eerder heb voorgesteld. Deze toepassing is wat we tegenwoordig noemen een stamceltransplantatie. Vroeger werd dit een beenmergtransplantatie genoemd omdat die cellen vrijwel altijd uit het beenmerg gehaald werden, tegenwoordig zijn we met allerlei trucs in staat deze cellen uit het bloed te halen waardoor deze procedure meer algemeen stamceltransplantatie genoemd wordt.

Acute leukemieën zijn ziektes die gekenmerkt worden door een snel delende populatie in het beenmerg en zich ook uiten in een snel optreden van symptomen. Onbehandeld heeft deze ziekte een zeer slechte overleving. Het is een heel acuut ziektebeeld, vandaar de naam. In het verleden was tegen deze ziekte geen kruit gewassen. Met name in het tijdperk van bloedzuigers en aderlatingen. Later kon alleen iets gedaan worden met een aanvulling van de tekorten, van bloedcellen zoals met behulp van transfusies. Chronische aandoeningen, daarentegen, hebben een overleving van maanden soms zelfs vele jaren en worden gekarakteriseerd door een teveel aan bloedcellen. Van oudsher kon dit vaak behandeld worden (zij het symptomatisch) met behulp van aderlatingen en in het verre verleden zelfs ook nog bloedzuigers. $U$ begrijpt, dit was een slechts op symptomen gerichte therapie, het verwijderen van wat er te veel is. Toegenomen inzicht laat ons deze behandeling nu gelukkig op een andere manier uitvoeren.

Het beenmerg en bloed bevinden zich overal in het lichaam en u zult begrijpen dat een locale behandeling van een kwaadaardige ziekte van het bloed of beenmerg zoals met chirurgie of het bestralen van een stukje van het lichaam niet echt een oplossing is van het probleem. Je behandelt slechts het topje van de ijsberg. Om deze reden heeft chemotherapie, de behandeling met medicijnen, een zeer belangrijke rol 
gekregen. Medicijnen komen door het gehele lichaam. Sinds de ontwikkeling van chemotherapeutica in de zestiger en zeventiger jaren van de vorige eeuw heeft deze behandelingsmodaliteit een enorme ontwikkeling doorgemaakt. We hebben in al die decades geleerd dat het voorzichtig behandelen met lage doseringen chemotherapie m.n. gericht op het voorkómen van bijwerkingen niet echt heeft bijgedragen aan een verbetering van overleving van acute ziektes. Een zeer stevige aanpak, erop gericht om met hoge doseringen chemotherapie de delende kwaadaardige populatie uit te roeien en op die manier weer het normale beenmerg een kans te geven normale bloedcellen te gaan maken, heeft wel geleid tot vooruitgang en betere resultaten. Maar $u$ begrijpt, dit zijn heel intensieve therapieën, vandaar dat dit vakgebied tegenwoordig de haematologische intensieve zorg genoemd wordt. Niet dat de behandeling gekenmerkt wordt door allerlei monitors en beademingsapparaten, zoals zo vaak gezien worden op intensive care afdelingen. Maar wel wordt deze aanpak gekenmerkt door de uiterst intensieve zorg voor de patiënt bij wie wij de aanmaak van bloed gedurende enkele weken hebben plat gelegd en waarbij we alles in het werk moeten stellen om de patiënt in leven te houden tot de normale bloedaanmaak zich weer hersteld heeft. Gewoonlijk is dit een periode van 3-4 weken, waarbij het aanvullen van tekorten met behulp van transfusies een heel belangrijke rol speelt. De ontwikkelingen op het gebied van de bloedtransfusies (ook een onderdeel van ons vak) zijn hierbij van eminent belang gebleken. Aangezien we tot op heden niet goed in staat zijn om witte bloedcellen aan te vullen en dit heel belangrijke cellen zijn in het kader van de bestrijding van infecties, is het voorkómen en behandelen van infecties een uitermate belangrijke taak. Om deze reden zult $u$ ook ervaren dat in de dagelijkse praktijk haematologen een zeer goede kijk hebben op het bestrijden van infecties en het infectiebeleid in het ziekenhuis. Het voorkómen en bestrijden van infecties is nu eenmaal onze dagelijkse activiteit in het kader van de haematologische intensieve zorg. Ik hoop echter niet dat $u$ hieruit de conclusie trekt dat de haematologische intensieve zorg zich beperkt tot het intensief opvangen van de somatische complicaties bij de patiënt. Een optimale haematologische intensieve zorg heeft ook aandacht voor de psychosociale aspecten van de patiënt en last but not least ook zijn directe sociale netwerk. Deze haematologische intensieve zorg maakt het ons mogelijk om deze patiënten gedurende meerdere weken met een sterk verzwakte afweer in leven te houden. 
Een volgende stap in de behandeling van de acute maar ook van sommige chronische leukemieën is de stamceltransplantatie geworden. Deze borduurde in eerste instantie voort op de hoge doseringen of zelfs ultra hoge doseringen chemotherapie en soms zelfs totale lichaamsbestraling met het idee dat daarmee de laatste kankercel in het lichaam verwijderd kon worden. Deze behandeling kan echter leiden tot irreversibele schade van het beenmerg waardoor een patiënt nieuw beenmerg nodig heeft. Immers zonder bloed en beenmerg kan een mens niet leven. Hiervoor zijn in principe meerdere bronnen mogelijk. Allereerst het eigen beenmerg van de patiënt zelf. $U$ zult begrijpen dat dit alleen maar een zinvolle actie is als hierin geen of een minimaal aantal kwaadaardige cellen aanwezig zijn. Een andere bron bestaat uit het gebruik maken van beenmerg van een donor. Dit heeft het grote voordeel dat hierin geen kwaadaardige cellen aanwezig zijn omdat we hier van doen hebben met een gezonde donor. Het grote probleem waarmee we echter geconfronteerd worden, heeft te doen met het feit dat het beenmerg ook bron is van het afweerapparaat. Het transplanteren van beenmerg van een gezonde donor naar een patiënt leidt dan ook tot het transplanteren van het afweerapparaat van de donor naar de patiënt. En dit kan leiden tot afstotingsproblemen. Niet zozeer in de zin dat het beenmerg door de patiënt wordt afgestoten, want de patiënt is hier door zijn zware behandeling veelal niet meer toe in staat. Neen, het grootste probleem wordt gevormd door de afstoting van de patiënt zelf door het beenmerg van de donor. Het is door jarenlange research gebleken dat m.n. de T-lymfocyten hiervoor verantwoordelijk zijn. Om deze reden is het dan ook in diverse ziekenhuizen praktijk geworden om deze T-cellen uit het transplantaat te verwijderen. Dit resulteert inderdaad in een afnemende kans op omgekeerde afstotingsziekte. Deze omgekeerde afstotingsziekte wordt in de praktijk graft-versus-host ziekte genoemd. Mocht iemand hopen dat met het verwijderen van de T-lymfocyten uit het transplantaat alle problemen opgelost zijn, helaas is dat niet zo. Het blijkt allemaal veel ingewikkelder te zijn en houdt ons als dokters en onderzoekers van de straat. Het blijkt nu dat wanneer de Tcellen uit het transplantaat verwijderd worden er een grotere kans bestaat dat de kanker terugkomt. Blijkbaar spelen de T-cellen een belangrijke rol in het voorkomen van het recidief van de ziekte. Deze waarneming heeft er later toe geleid dat T-cellen van dezelfde donor na een transplantatie worden toegediend. Hierbij is gebleken dat bij diverse ziektes een recidief van de ziekte na transplantatie genezen kan worden met behulp van lymfocyten (de afweercellen) van de donor, de 
zogenaamde donor lymfocyten infusies. Het blijkt dus dat het toedienen van donor lymfocyten een antitumor effect heeft dat gelijkwaardig of misschien zelfs wel sterker is dan de massale hoeveelheden chemotherapie en totale lichaamsbestraling die in de praktijk gegeven werd. Dit heeft geleid tot een nieuw concept van stamceltransplantaties met behulp van donorcellen. Massale hoeveelheden therapie zijn niet meer nodig. Wat blijkbaar nodig is, is het vervangen van het afweerapparaat van de ontvanger, de patiënt, door dat van de donor. Vervolgens moet het donor afweersysteem de kanker in de ontvanger opruimen. Dit heeft zich ontwikkeld tot wat tegenwoordig de niet-myeloablatieve stamceltransplantaties genoemd wordt, ook wel populair gezegd mini-transplantaties. Deze behandeling is inderdaad veel minder intensief. Er worden geen massale hoeveel heden chemotherapie meer gegeven, maar er vindt een slimme subtiele onderdrukking plaats van de afweer van de patiënt waarna transplantatie plaats vindt. Vervolgens zorgt het donor beenmerg in de patiënt voor een immunologisch antitumor effect. Complicaties als gevolg van deze nieuwe toepassing zijn dan ook aanzienlijk beperkter. Natuurlijk is het wel zo dat de waarde van dit concept in de praktijk nog deels bevestigd moet worden. Deze nieuwe aanpak met minder complicaties heeft wel tot aanzienlijke verschuivingen in het veld aanleiding gegeven.

Doordat de kans op ernstige en fatale complicaties afneemt wanneer we mini-transplantaties toepassen, wordt de behandeling ook toegankelijk voor mensen voor wie een gewone stamceltransplantatie in het verleden te gevaarlijk was, zoals mensen op hogere leeftijd. Ook zal deze behandeling toegepast kunnen gaan worden bij ziektes waarbij in het verleden geen stamceltransplantaties met donoren werden toegepast, i.v.m. een ongunstige balans tussen kans op bijwerkingen en de mogelijke winst. In dat kader is er wel een doorbraak bij de behandeling van nierkanker. In ons eigen ziekenhuis worden deze behandelingen ook toegepast. Voorts hebben we een onderzoeksprogramma waarin de waarde van deze therapieën ook bij andere solide tumoren, zoals borstkanker, worden uitgetest. De vooruitgang die op dit gebied geboekt wordt, is vaak langzaam maar is toch de moeite waard gezien de grote aantallen patiënten met solide tumoren die op dit moment met de gangbare behandeling nog niet genezen kunnen worden.

$U$ ziet, dit is een beschrijving van ziektes die in het nog niet zo verre verleden niet behandeld konden worden of slechts met behulp van bloedzuigers of aderlatingen. Vervolgens hebben we de stap gemaakt naar de zeer intensieve therapieën waarbij we wel mensen konden 
genezen. Deze behandelingen zijn niet zonder bijwerkingen, reden waarom we momenteel een stapje terug zetten naar slimmere, minder intensieve behandelingen die mogelijk even effectief zijn. Een stapje terug in bijwerkingen maar hopelijk niet in effectiviteit. $U$ zult begrijpen dat het hier zeer ingewikkelde therapieën betreft die ook zeer kostbaar zijn. Dit dwingt ons tot een goede onderbouwing van de winst en de kosten (lees ook kans op complicaties voor de patiënt) van deze behandeling. Hiervoor is goed klinisch en preklinisch onderzoek noodzakelijk.

\section{Evidence Based Medicine}

Vrijwel alle stappen die ik hiervoor vermeld heb, zijn met behulp van wetenschappelijk onderzoek onderbouwd, voor een groot deel door gecontroleerd onderzoek, deels ook ongecontroleerd. De haematologie is een belangrijk voorbeeld van zoals het hoort: werken volgens het concept van "evidence based medicine".

Ik heb $\mathrm{u}$ zo juist dus verteld en hopelijk overtuigd dat er een immunologisch antitumor effect (een kankerremmend effect van het afweerapparaat) bestaat. Als ik $u$ dat van tevoren gevraagd zou hebben zou $u$ waarschijnlijk ook gezegd hebben dat de afweer een belangrijke rol speelt in het voorkómen en bestrijden van kwaadaardige ziektes. $U$ moet zich echter realiseren dat het bewijs van deze wijd verbreide mening pas zeer recentelijk is geleverd. Alternatieve genezers claimen dit effect al vele decades. Ze hebben tot op heden helaas nog geen mogelijkheid gezien om dit volgens de principes van "evidence based medicine" aan te tonen. Dit is een treurige ontwikkeling omdat elke behandeling hoe logisch die ook mag lijken in de praktijk niet hoeft te werken en, erger nog, een kans op bijwerkingen heeft. De hypothese dat natuurlijke geneesmiddelen en middelen die uit de natuur ontwikkeld worden onschuldig zijn moge duidelijk naar het rijk der fabelen worden verwezen.

Ik hoef hier maar te wijzen op deze mooie plantjes, het vingerhoedskruid: digitalis. Hoewel uit deze mooie planten een belangrijk geneesmiddel kan worden gemaakt dat ritmestoornissen van het hart kan bestrijden en de pompfunctie van het hart kan verbeteren, is dit een van de meest giftige stoffen die de natuur heeft voorgebracht. Ook diverse cytostatica die gebruikt worden in de behandeling van patiënten met kanker zijn afgeleid van natuurlijke stoffen, als voorbeeld het Doxorubicine maar ook Paclitaxel (Taxol) en Docetaxel (Taxotere). Dit zijn middelen die erg giftig zijn. Hetzelfde geldt ook voor allerlei extracten van de zwezerik, bron van de hele ontwikkeling van de T-cellen. "Baat het niet, het schaadt ook niet", 
bestaat niet in de geneeskunde. We zijn het aan onze patiënten verplicht de waarde van ons handelen te onderzoeken.

Het ware te hopen dat hetgeen wij in een brainstorm meeting met $z$ 'n allen bedenken of eventueel zelfs in een creatieve bui in de avonduren met een glas rode wijn, altijd een doorbraak betekent voor de behandeling. Toch moet dit altijd goed getoetst worden, bij voorkeur in onderzoek met een controlegroep. Helaas blijkt dan vaak dat wat zo logisch lijkt in de natuur en in de dagelijkse praktijk, niet altijd werkt.

Willen wij in de dagelijkse praktijk verder komen dan moeten we veel meer inzicht krijgen in het ontstaan en de hele ontwikkeling van de kwaadaardige ziekte. Waar gaat het verkeerd, waar zitten de primaire schakelfouten? Er is meer inzicht nodig in de hele samenstelling van het genetisch materiaal in de kankercellen. Dit is kostbaar en zeer ingewikkeld onderzoek. Gelukkig leidt dit tot nieuwe therapeutische opties. De nieuwe geneesmiddelen die hierop gebaseerd zijn grijpen selectiever aan op de kwaadaardige cellen. Daarom zijn ze hopelijk effectiever en mogelijk ook minder toxisch.

Echter het grote probleem van dit soort nieuwe behandeling zijn de enorme kosten die hieraan verbonden zijn. Een voorbeeld van deze nieuwe ontwikkelingen betreft het middel Imatinib dat de afgelopen jaren geïntroduceerd is in de behandeling van de chronische myeloïde leukemie. Het grijpt precies aan op de plek van de essentiële schakelfout. Tot voor kort was een stamceltransplantatie met behulp van donor stamcellen de standaard behandeling bij patiënten met een chronische myeloïde leukemie. De introductie van Imatinib heeft dit helemaal op zijn kop gezet. Het aantal patiënten dat direct getransplanteerd wordt voor deze aandoening is sterk gereduceerd. Vrijwel alle patiënten krijgen nu eerst een behandeling met behulp van Imatinib. Dit valt ook wel te begrijpen. Een keuze tussen enkele pillen per dag of een ziekenhuisopname en een transplantatie met ook nog risico's op complicaties en overlijden is voor veel artsen en patiënten een eenvoudige. Echter, het betreft hier een behandeling met een prijskaartje van ongeveer $€ 80$ per dag, ongeveer $€_{30.000}$ per jaar. Gelukkig is dit middel toegelaten tot de markt en kan het worden voorgeschreven. Het kan worden voorgeschreven via de stadsapotheek en het wordt vergoed door de ziektekostenverzekeraars. Een heel ander probleem vormen de nieuwe middelen die via infusen moeten worden toegediend.

Volgens de regelgeving is dit een ziekenhuisverstrekking en moet het middel via en door het ziekenhuis verstrekt worden. Het ziekenhuis krijgt voor enkele maar niet alle van deze middelen een vergoeding tot 
$75 \%$ en moet dus uit het eigen, algemene budget minstens $25 \%$ zelf bijlappen. Het betreft hier middelen als Trastuzumab (Herceptin) maar ook Rituximab (Mabthera). Ook veel gebruikte middelen als Paclitaxel (Taxol) en Docetaxel (Taxotere) vallen onder deze regeling. $U$ ziet dat het om grote bedragen gaat. Ook ziet $u$ dat het aantal patiënten dat winst boekt met deze middelen enorm stijgt. Omdat het geld maar een keer uitgegeven kan worden, is het gevolg dat er op andere uitgaven (lees: patiënten) bezuinigd moet worden.

$U$ begrijpt dat dit leidt tot enorme budgettaire consequenties voor de ziekenhuizen. Voor onze dokters leidt dit tot nog veel grotere problemen. Wij hebben namelijk een behandelingsovereenkomst met de patiënt. We moeten en willen hem of haar de beste en meest kosteffectieve behandeling geven. De budgettaire consequenties hiervan voor het ziekenhuis horen niet in de spreekkamer thuis. Het is niet een discussie die de dokter in een vertrouwensrelatie met zijn patiënt in de spreekkamer moet voeren, hier moet de politiek duidelijke richtlijnen geven. Ik durf hier stellig te beweren dat een politicus in de patiëntenrol, deze geneesmiddelen wil hebben. Het erkennen en toelaten in Nederland van een geneesmiddel op basis van wetenschappelijk onderzoek voor een bepaalde indicatie maar vervolgens zeggen dat maar maximaal drie kwart van de prijs daarvan vergoed wordt is geen logische keus. De ander optie, n.l. de patiënt deze $25 \%$ laten betalen, lijkt mij in een welvarend land als Nederland een keus passend bij een zeer slecht sociaal gevoel. Dit betekent dat sommige mensen, die het kunnen betalen de behandeling krijgen en anderen die het niet kunnen betalen de behandeling niet krijgen. Nederland is zo welvarend dat dit op een andere manier opgelost moet kunnen worden.

Deze budgettaire discussies leiden tot een grote ambivalentie bij de dokters. Van de ene kant zijn we blij dat onderzoek heeft geleid tot een nieuw effectief middel en dat we onze patiënten die lijden aan deze ernstige ziektes, die je zelfs je grootste vijand niet toewenst, kunnen helpen, aan de andere kant leidt dit tot allerlei budgettaire problemen en interne discussies in het ziekenhuis. Dit leidt ertoe dat we blij moeten zijn wanneer een nieuw geneesmiddel niet effectief is. De wereld op zijn kop. We willen toch niet meer terug naar goedkope maar weinig effectieve behandelingen zoals aderlatingen en bloedzuigers?

In die context is het relevant om eens te kijken waar in Nederland het geld voor geneesmiddelen uitgegeven wordt. In een recente uitgave van de Stichting Farmaceutische Kengetallen valt te lezen dat er in Nederland jaarlijks een kleine 4 miljard Euro wordt uitgegeven aan 


\begin{tabular}{|l|l|}
\hline \multicolumn{2}{|l|}{ Zorgbudget Nederland 1999} \\
\hline Psychische stoornissen & $21,6 \%$ \\
\hline Hart- en Vaatziekten & $10,1 \%$ \\
\hline Bewegingsstelsel & $5,5 \%$ \\
\hline Nieuwvormingen & $4,0 \%$ \\
\hline
\end{tabular}

Kosten van ziekten in Nederland. RIVM 1999

geneesmiddelen. Van deze 4 miljard wordt ongeveer $€ 800$ miljoen uitgegeven aan 2 miljoen patiënten voor zgn. hart- en vaatmiddelen, zoals bloeddruk- en cholesterolverlagers etc. Daarnaast geven wij ongeveer $€ 600$ miljoen uit aan maagzuurremmers e.d. Het betreft hier een kleine 2 miljoen patiënten. Ook nog een $€ 550$ miljoen voor antidepressieva en slaapmiddelen voor 2.2 miljoen patiënten (2). Van het totale zorgbudget in Nederland wordt $4 \%$ uitgegeven aan de behandeling van kanker (3). In 2002 was dit $€ 178$ miljoen. Geen klein bedrag maar vergeleken met de andere ziektecategorieën, zoals hart- en vaatziekten een relatief bescheiden bedrag.

in de top tien van de geneesmiddelen uitgaven komt in 2002 geen enkel middel voor dat in de haematologie of oncologie gebruikt wordt, hoewel deze aandoeningen verantwoordelijk zijn voor de dood van ongeveer een op de drie Nederlanders.

Nadere bestudering van de richtlijn hoge bloeddruk leert mij dat de aanbeveling om deze mensen te behandelen voor een hoog cholesterol (en dat zijn er heel veel) alleen maar geldt voor die mensen die naast een hoge cholesterolspiegel in het bloed en een hoge bloeddruk ook dienen te roken (4). Zonder roken komt men niet snel in aanmerking voor een cholesterolverlagende behandeling. Het is absurd dat mensen vrijwillig een extra risicofactor dienen te introduceren om in aanmerking te komen voor een behandeling. Absurd om zelfs maar even na te denken over het introduceren van dit gedrag bij kanker patiënten.

Het moge duidelijk zijn dat de bovengenoemde effecten alle het gevolg zijn van de budgettering van de gezondheidszorg. Budgettering van de gezondheidszorg is een financiële maatregel die niet gericht is op het bevorderen van de kwaliteit. Hooguit (en dan moet je het gebeuren wel heel welwillend beschouwen) het bevorderen van de efficiency. Waar wij in Nederland met $z$ 'n allen behoefte aan hebben is het bevor- 
deren van kwaliteit voor zo laag mogelijke kosten. Het vaststellen van een bepaald plafond aan de kosten is niet echter een kwaliteitsbevorderende maatregel. Deze zouden wel eens strijdig kunnen zijn.

Het op financiële gronden onthouden van bepaalde prijzige behandelingen aan onze patiënten, betekent kwalitatief gezien de klok terugzetten. We gaan weer terug richting de goedkope niet effectieve therapieën: van aderlatingen en bloedzuigers(vroeger) naar de effectieve stamceltransplantaties (nu); en weer terug naar goedkope maar minder effectieve behandelingen uit het verleden. Wat zouden onze politici in de patiëntenrol willen?

\section{Toekomstontwikkelingen: wat gaan wij doen in de nabije toekomst}

Wat gaan we in de toekomst doen met de nieuwe kennis dat de gezonde afweer in staat is om bepaalde soorten kankers te bestrijden, soms zelfs te genezen. Hoe kunnen wij de immunotherapie, de bestrijding van kanker met behulp van het afweerapparaat, verbeteren.

Ik heb $\mathrm{u}$ al eerder beschreven dat een stamceltransplantatie met behulp van donor stamcellen in staat is om een immunologisch antitumor effect op te roepen. Wij hebben dit tot een belangrijk item van ons onderzoek gemaakt. Klinisch passen we deze transplantaties toe bij patiënten met diverse haematologische aandoeningen maar ook, in onderzoeksverband, bij verschillende solide tumoren. Het gaat hier om het uitzoeken welke patiënten met dit soort behandelingen gebaat zijn. We doen dit met het direct toepassen ervan.

In het laboratorium proberen wij echter de werkingsmechanismen te ontrafelen en m.n. ook te bekijken hoe we deze effecten kunnen versterken. Hoewel we in de kliniek nog gericht zijn op de effecten van de Tlymfocyten, is het duidelijk dat natural killer cellen en dendritische cellen een zeer belangrijke rol spelen. Zij zijn waarschijnlijk erg belangrijk voor de manier waarop kankercellen aangeboden worden aan het afweerapparaat en vervolgens ge"killed" worden. Dit is een heel belangrijk item van ons onderzoek. Ik prijs mij dan ook gelukkig dat onze groep in het laboratorium een analyse van deze immunologische antitumor effecten maakt. Onder leiding van Gerard Bos uit onze groep, samen met Michel van Gelder, Monique Grommé, Wilfred Germeraad, Ellen van Leeuwen en de AlO's Arianne Vanclee en Silvy Cloosen, bestuderen wij aspecten als post-transplantatie vaccinaties en het gebruik van dendritische cellen.

Met de afnemende grootte van de gezinnen, ook in Limburg, zal het aantal patiënten dat in het bezit is van een HLA identieke broer of zus 
alleen maar afnemen. Een van de nieuwe opties betreft het zoeken van donoren in donorbanken. Er zijn andere haematologische afdelingen in Nederland die hier uitgebreid aan werken. Wij willen ons focussen op het gebruik van half-identieke donoren. Voortbordurend op belangrijk werk, gedaan in Italië (de groep van Martelli in Perugia), zullen wij transplantaties gaan doen met behulp van haplo-identieke donoren. Een van de belangrijke voordelen, naast het feit dat vrijwel iedereen een donor heeft, is de sterke anti-tumor werking van natural killer cellen in deze setting. Dit is een heel zinvolle aanvulling op ons T-cel programma. $U$ zult begrijpen dat dit een hele investering vraagt, zowel van mankracht maar ook financieel. Om deze reden is het dan ook erg belangrijk dat de faculteit Geneeskunde maar met name ook het academisch ziekenhuis Maastricht dit soort ontwikkelingen ondersteunt. Zelfs in deze, voor het azM, moeilijke tijden rekenen we op deze steun. Het feit dat bij mijn benoeming 2 achtereenvolgende voorzitters van de Raad van Bestuur van het az $M$ betrokken zijn geweest en goedkeuring hebben gegeven maakt deze steun vanzelfsprekend. $U$ begrijpt ook dat het niet verder ontwikkelen van het stamceltransplantatie programma resulteert in een niet te overbruggen achterstand t.o.v. andere centra in Nederland zodat vroeg of later het stoppen noodzaak zal zijn. Zullen we in dat geval weer terug gaan naar de aderlatingen en de bloedzuigers?

Ik heb $u$ al eerder verteld dat wij allogene stamceltransplantaties toepassen als deel van de behandeling van patiënten met solide tumoren. In dit verband is het van belang om de betrokkenheid van onze oncologen Rob Jansen, Pierre Hupperets, Ruud van Rijswijk en Roy Lalisang en de collega's in de regio te vermelden. Ook de toenemende samenwerking over de grenzen met de collega's in Aken (prof. Osieka) en de ontluikende samenwerking richting het Belgische zorggebied, m.n. het ziekenhuis in Tongeren zijn in dat kader van belang. De oudste steden van België en Nederland hebben elkaar gevonden. Graag zouden wij ook in de nabije toekomst willen samenwerken met de collega's in Luik. Daarnaast moeten de belangrijke Europese netwerken, zoals de EBMT, nog genoemd worden. Ik vind het dan ook van enorm belang dat de voorzitter van de EBMT, Prof Jane Apperley, hier aanwezig is.

In het Nederlands perspectief ligt Maastricht in een uithoek, een soort appendix. Het is zelfs zo dat de afstand vanuit de Randstad naar Maastricht veel groter is (of is het slechts lijkt) dan de afstand van Maastricht naar de Randstad. Bekijken we het echter meer in de toekomst en gaan we ervan uit dat vroeger of later de landsgrenzen zullen vervagen, of misschien zelfs wel verdwijnen, dan ligt Maastricht in het 
hart van Europa. In samenwerking met anderen kunnen we hier iets groots opbouwen.

Een heel belangrijke nieuwe ontwikkeling betreft de vinding dat sommige stamcellen uit het beenmerg in staat lijken te zijn om zich te ontwikkelen tot hersencellen en ook tot hartcellen. in een recentelijk opgestarte samenwerking met collega Waltenberger van de afdeling cardiologie van het azM willen wij proberen ons steentje bij te dragen aan de ontwikkeling van deze belangrijke nieuwe modaliteit waarin gebruik gemaakt wordt van beenmergcellen. Indien ook andere disciplines in de nabije toekomst behoefte hebben aan samenwerking met ons op het gebied van beenmergstamcellen, die zij willen gebruiken voor orgaanreparaties, zijn zij van harte welkom. Wij zijn bereid om alle mogelijke ondersteuning te leveren.

Bij dit soort behandelingen komen kwaliteit van leven aspecten uitdrukkelijk aan de orde. In dit kader is het van belang even kort onze initiatieven op het gebied van thuisbehandeling van leukemie patiënten te melden. Patiënten met haematologische aandoeningen zijn langdurig in het ziekenhuis. Dit heeft te maken met hun verminderde afweer. Uit onze recente pilot trial blijkt echter dat een ziekenhuisopname niet altijd voor de hele periode noodzakelijk is en dat een deel van de patiënten de behandeling en m.n. de ondersteunende behandeling thuis kunnen krijgen. Ik hoop dat we in staat gesteld kunnen worden om dit project verder uit te werken. Dit dient m.n. gericht te zijn op veiligheid, maar ook op kwaliteit van leven van de patiënt en daarnaast ook op de ondersteuning van de zorgverleners thuis.

Wij zijn ons er toenemend van bewust dat wij, in een poging tot genezing, veel (vaak tijdelijke) schade aanrichten. Ook leiden onze behandelingen slechts op langere termijn tot een verbetering van kwaliteit van leven. In dit kader is het van belang het samenwerkingsverband met Annemie Courtens te melden waarin gestudeerd wordt op door chemotherapie geïnduceerde vermoeidheid. Nynke de Jong is de onderzoekster die dit onderwerp met niet aflatende energie te lijf is gegaan.

In onze behandelingen tasten we de natuurlijke weerstand van de patiënt aan. Ter voorkoming van ernstige infecties worden allerlei maatregelen genomen zoals verpleging in een beschermde omgeving en het gebruik van diverse dieetmaatregelen. Samen met Frank van Tiel van de Medische Microbiologie hebben we onderzoek naar de noodzaak en de onzin van dit soort maatregelen op dit gebied lopen. Recentelijk is de 
McBav studie afgerond met als onderwerp het belang van bacteriearme voeding en voorts analyseren we de noodzaak van dit soort behandelingen in het ziekenhuis in plaats van thuis. In dit verband is ook de ondersteunende transfusietherapie te noemen onder leiding van Lizzy van Pampus en Karly Hamulyak.

Ik heb reeds eerder gesproken over "evidence based medicine". Om evidence op te bouwen is klinisch onderzoek noodzakelijk. Zeker bij relatief weinig voorkomende aandoeningen is dit de enige manier om te zorgen dat de behandeling van morgen significant beter is dan die van gisteren. De protocollen voor dit soort studies zijn toenemend ingewikkeld en soms zelfs te ingewikkeld. In een poging dit allemaal meer toegankelijk te maken werken we samen met Arie Hasman, Jan Talmon en Huibert Tange van de afdeling Medische Informatica. Eugenie van Oosterhout gaat binnen afzienbare tijd op dit onderwerp promoveren.

In de toekomst krijgen we in toenemende mate te maken met oudere patiënten. Haematologische en oncologische aandoeningen zijn aandoeningen van patiënten met een gemiddelde leeftijd boven de 60 jaar. Gelukkig worden de behandelingsresultaten beter waardoor er meer patiënten met kanker in leven blijven. Daarnaast is het ook zo dat Nederland vergrijst. Elk jaar wordt het compartiment ouderen 1 à $2 \%$ groter zodat in de nabije toekomst door deze dubbele vergrijzing het aantal oudere patiënten enorm toeneemt. Het is zo dat wij nog steeds heel veel kunnen leren met betrekking tot de aanpak van de oudere patiënt. Daarom ben ik er ook vast van overtuigd dat wij in ons (poli)klinisch onderzoek meer aandacht moeten gaan besteden aan deze oudere patiënten. Om deze reden prijs ik me dan ook gelukkig betrokken te zijn bij een nationaal initiatief waarbij we de tekortkomingen in diagnostiek en behandeling van de oudere patiënt en ook de begeleiding van de oudere patiënt bestuderen. Het is een feit dat de gemiddelde oudere Nederlander veel langer leeft dan menige dokter zich realiseert. Dit is een aspect dat zeer nauwgezet betrokken dient te worden in de afwegingen welke behandelingen aan te bieden aan de oudere patiënt en welke behandelingen misschien niet meer.

We willen dat liefst doen op een manier waarbij we de fouten uit het verleden proberen te voorkomen. Patiënten die in het verleden niet behandeld werden of niet adequaat genoeg behandeld werden momenteel zeer intensief behandeld worden. Mogelijk is dit ook weer te intensief. Het is een uitdaging te werken aan nieuwere therapieën die minder intensief zijn zodat ze ook door oudere patiënten met diverse comorbiditeiten verdragen kunnen worden. We moeten hierbij werken 
aan slimmere oplossingen zonder ons te laten verleiden terug te gaan naar bloedzuigers of aderlatingen.

\section{Onderwijs}

Zoals ik eerder in het betoog heb uiteengezet vormt de hele bloedaanmaak - haematopoiese - een schoolvoorbeeld van wat er gebeurt binnen een mens. Proliferatie en differentiatie en het evenwicht hiertussen. Om deze reden ben ik er dan ook van overtuigd dat haematologie en oncologie een heel belangrijke rol kunnen spelen binnen het onderwijs voor medisch studenten. De principes van pathogenese, supportive care, de behandeling van haematologische aandoeningen en de begeleiding van de haematologische patiënt kunnen leiden tot vele leermomenten. Het blijkt dan ook dat wanneer medisch studenten de moed kunnen opbrengen om bij ons een stage van enkele weken of maanden te volgen, ze vrijwel allemaal met heel veel enthousiasme de afdeling verlaten. Blijkbaar heeft het vak een stuk enthousiasme losgemaakt. Bekend maakt bemind.

Helaas worden we op onze afdeling Interne Geneeskunde geconfronteerd met vele arts-assistenten die kiezen voor het aandachtsgebied "vascular medicine". Natuurlijk is het zo dat de behandeling van patiënten met hypertensie, diabetes mellitus en allerlei andere vasculaire aandoeningen uitermate belangrijk is. Het gaat echter niet alleen om de vaatwand, het gaat met name om wat er doorheen stroomt. Wij kunnen jullie niet alleen veel leren op het gebied van de supportive care (transfusiebeleid antibiotica/infectiebeleid) maar ook de algemene interne geneeskunde (electrolietproblemen, nierfunctiestoornissen, leverproblemen, etc). Onze afdeling is de meest algemene afdeling binnen de Interne Geneeskunde.

Wij hopen met een hernieuwde aandacht voor de opleiding bij potentiële aandachtsgebieders een nieuw enthousiasme los te maken. Waarschijnlijk zijn we hier in het recente verleden tekort geschoten. We hebben echter de ambitie, en ik niet alleen maar onze hele groep heeft de ambitie, om jullie hiervoor te enthousiasmeren. Wij hopen dat dit op korte termijn vruchten zal afwerpen.

Mogelijk bent $u$ op de hoogte van de speciale situatie waarin wij in het azM werken. Binnen de interne Geneeskunde hebben we een gecombineerde divisie Haematologie en Oncologie. Hoewel er vele overeenkomsten zijn, groeien de klinische activiteiten uit elkaar. We kunnen dat betreuren, echter het is een feit. Het aantal specialisten, dat een academische carrière ambiëert en én oncologisch én haematologisch 
geschoold is, is tot vrijwel nul gedaald. Wij zijn met ons samenwerkingsmodel langzaam een roepende in de woestijn geworden. We kunnen misschien wel gelijk hebben, maar krijgen het niet. De medische oncologie is in Nederland een eigen weg ingeslagen. Nu de invulling van de vacature Medische Oncologie aanstaande is, is het naar mijn mening van het grootste belang dat we een formule vinden waarin we de ontwikkeling van beide disciplines Haematologie en Oncologie zoveel mogelijk faciliteren. Samenwerking op gebied van pre-klinisch en misschien ook wel klinisch onderzoek voor zover de focus identiek is. Ook samenwerking op het gebied van opleiding van medische studenten. Apart voor de verdere ontwikkeling van de zorg. 


\section{Dankwoord}

Op het einde van deze rede past het om openbaar dank te zeggen. Hier bestaat het grote gevaar iemand te vergeten. Om die reden begin ik te melden dat de haematologische intensieve zorg en stamceltransplantaties in het academisch ziekenhuis Maastricht gekenmerkt worden door een multi-disciplinaire aanpak, waarbij meer dan 200 mensen betrokken zijn. Hen allen ben ik heel veel dank verschuldigd, ook voor hun loyaliteit en support. Ik hoop dat onze samenwerking alleen nog maar beter en effectiever kan worden in het belang van onze patiënten.

Ik dank het College van Bestuur van de Universiteit Maastricht en het Bestuur van de Faculteit der Geneeskunde voor het vertrouwen dat ze in mij stellen. Om diezelfde reden dank ik ook de Raad van Bestuur van het Academische Ziekenhuis Maastricht en het bestuur van de Stichting Annadal.

Ik dank voorts dr. Heering. Beste Karel. Jij bent je mogelijk niet bewust van het feit dat je aan de wieg hebt gestaan van mijn haematologische carrière. Toen ik 3 dagen na het behalen van mijn artsenbul aan de universiteit van Utrecht begon met mijn interne opleiding in het Bleulandziekenhuis in Gouda was jij mijn eerste supervisor. Ik werd voor de leeuwen gegooid. Jij hebt mij de beginselen van de interne geneeskunde geleerd. Dat ging niet altijd gemakkelijk. Patiëntenbrieven werden zeer nauwgezet gecorrigeerd. Specialiténamen werden vervangen door generische, etc. Hier heb ik de eerste patiënten met chemotherapie behandeld en ben ik terecht gekomen op de haematologische besprekingen die meerdere keren per jaar op de zaterdagochtenden in de Daniel den Hoed gehouden werden. Dit heeft mijn belangstelling voor de haematologie versterkt. In latere jaren ben je opleider geworden, zelfs zonder gepromoveerd te zijn. Dit heeft mij ook enige tijd gestimuleerd tot het idee dat promotie voor een goede carrière niet noodzakelijk was. Pas later door het fellowship van het Koningin Wilhelminafonds en de invloed van Geert Blijham heb ik gemerkt dat voor mijn verdere ontwikkeling ook onderzoek en publicaties zinvol zijn.

Tijdens het tweede deel van mijn interne opleiding kwam ik terecht in het Zuiderziekenhuis in Rotterdam. Via prof. Birkenhäger, die helaas hier niet aanwezig kan zijn, ben ik uitgebreider in contact gekomen met de Daniel den Hoed. De zeer goede klinische blik van Willemijn Sizoo in combinatie met de wetenschappers Bob Löwenberg, Ton Hagenbeek en Mars van 't Veer hebben geleid tot vele leermomenten. Door jullie steun 
werd ik klinisch fellow van het Koningin Wilhelminafonds/Nederlands Kankerbestrijding en kwam ik terecht in Omaha, Nebraska. Het was een hele uitdaging om met het hele gezin midden in de winter in Nebraska te arriveren. Daar aankomen bij een temperatuur van min $30^{\circ} \mathrm{Celsius}$ en opgevangen worden door mijn nieuwe baas, Jim Armitage, en zijn vrouw, die ons hielpen met onze 20 koffers. De financiering door de collectebussen maakte het belangrijk om alles zo goedkoop mogelijk te houden. Jullie welkom en de verdere opvang gedurende dat jaar in Nebraska heeft ons heel veel goed gedaan. Dit jaar heeft geresulteerd in vele publicaties en ook in mijn proefschrift. Ik zou niet weten hoe mijn carrière verlopen zou zijn indien ik niet in Omaha terecht was gekomen.

$\mathrm{Na}$ mijn verblijf in Omaha en een korte tussenstop in het AZU, kwam ik terecht in het academisch ziekenhuis Maastricht. Ik kwam in een kleine groep van in totaal 4 haematologen/oncologen onder leiding van Geert Blijham. De filosofie was en is nog steeds dat haematologie en oncologie veel voor elkaar kunnen betekenen. Wij hebben met z'n allen hieraan gewerkt. Het heeft geresulteerd in een staf samenstelling die nu, naaste enkele onderzoekers, uit ongeveer 10 internisten bestaat. Helaas is Geert te vroeg vertrokken voor andere uitdagingen, die meer in zijn carrièrelijn pasten. Ik zou het gewaardeerd hebben, indien hij nog een aantal jaren langer in Maastricht gebleven zou zijn.

De collegae van de werkgroep Haematologie-Oncologie dank ik voor de zeer intensieve samenwerking. Ook al onze hulptroepen, zoals secretaresses, stamceltransplantatiecoördinatoren, researchverpleegkundigen, datamanagers, kwaliteitsmanager, etc. Het is werkelijk een genoegen maar ook een continue uitdaging om voor en met jullie te mogen werken.

De collegae in de met ons samenwerkende ziekenhuizen in Limburg, zuid-oost Brabant en Belgisch Limburg. Er is een tijd geweest dat we elkaar in de regio heftig beconcurreerden. Gelukkig is deze tijd nu achter ons en hebben we geleerd om, met respect voor elkanders eigenheid, samen te werken in het belang van de patiënten die ons zijn toevertrouwd. Hoogstaande zorg in deze regio moet onze doelstelling zijn. Wij hebben elkaar hiervoor nodig en we kunnen veel van elkaar leren.

Een speciaal woord van respect voor onze patiënten en hun familieleden. Ik realiseer me vaak, maar mogelijk niet vaak genoeg, wat voor ellende wij $u$ aandoen. Onze behandelingen leiden zeker op korte termijn niet altijd tot een goede kwaliteit van leven. Ook zullen we ongetwijfeld fouten maken en verkeerde inschattingen. Ik hoop dat $u$ erop vertrouwt dat wij ons allen, met alle beperkingen, zeer inspannen om 
uw noodlot van een zeer ernstige, levensbedreigende ziekte om te buigen in een positieve toekomst die het lijden allemaal waard was en het weer snel doet vergeten. Wij doen het voor $u$ en uw opvolgers. Ik vrees dat het er nog velen zullen zijn voordat wij slim genoeg zijn om u op een eenvoudiger manier te kunnen genezen. Niet meer met aderlatingen of bloedzuigers. Mogelijk wel nog met een goede intensieve haematologische zorg en met slimmere stamcel transplantaties. Hopelijk, met minder belastende en nog effectievere behandelingen in de toekomst.

Een groep die in mijn verhaal nog niet specifiek genoemd is zijn onze verpleegkundigen, met name van onze verpleegafdeling As en het interne dagcentrum. Jullie ongelooflijke inzet voor de patiënt helpt ons op een enorme manier. De samenwerking met jullie is van een niet te beschrijven belang voor het primaire proces.

Het is bedroevend dat benoemingsprocedures zo lang duren dat mijn ouders hier niet meer aanwezig kunnen zijn. Zij stonden aan de wieg van deze ontwikkeling. Mijn vader zou hier maar wat graag aanwezig zijn geweest, maar helaas is hij een jaar geleden overleden. Mijn moeder is niet meer in staat hier aanwezig te zijn. Het moest zo zijn, helaas.

In 1991 mocht ik hier mijn proefschrift verdedigen. Het werd toegewijd aan 4 dames en een heer. Ik prijs me gelukkig dat deze club nog steeds bij elkaar is. Er is zelfs een dame bijgekomen die blijkbaar mijn plaats heeft ingenomen. Marieke, Femke, Gerben, Viviane en Alice bedankt voor jullie grote steun, liefde en oneindig begrip. Uit het feit dat twee van jullie ook voor de geneeskunde kiezen, leid ik af dat ik nog niet zo'n slecht voorbeeld heb gegeven.

Ik ben een zeer tevreden mens. Maar er zijn nog vele uitdagingen.

Ik heb gezegd. 


\section{Referenties}

(1) Snijder S, Coeberg JWW, Otter R, Visser O, Schouten U. Hematological Malignancies in the Netherlands. 1989-1995. Association of Comprehensive Cancer Centers, 1999.

(2) Stichting Farmaceutische Kengetallen. Data en Feiten 2003. Stichting Farmaceutische Kengetallen, 2004.

(3) Polder JJ, Takken J, Meerding WJ, Kommer GJ, Stokx U. Kosten van ziekten in Nederland. RIVM rapport. 2002.

(4) Wiersma Tj, Walma EP, Thomas S, Assendelft WJJ. Samenvatting van de standaard 'Hypertensie' (derde herziening) van het Nederlands Huisartsen Genootschap. Nederlands Tijdschrift voor Geneeskunde 148[19], 923-931. 8-5-2004. 
